\title{
SELEKTIVITAS BUBU BUTON DI PERAIRAN DESA WAKAL, KABUPATEN MALUKU TENGAH
}

\author{
Selectivity Of Pot In Wakal village Water, and Central Maluku Regency
}

\author{
Oleh: \\ Kedswin Gerson Hehanussa ${ }^{1}$, Sulaeman Martasuganda ${ }^{2}$, Mochammad Riyanto ${ }^{2}$ \\ ${ }^{1}$ Mahasiswa Pascasarjana Departemen PSP FPIK IPB \\ ${ }^{2}$ Staf Pengajar Jurusan Teknologi Perikanan Laut \\ "Korespondensi: kedswinhehanussa@gmail.com
}

\begin{abstract}
ABSTRAK
Nelayan di Perairan Desa Wakal menggunakan alat tangkap bubu untuk menangkap ikan karang. Bubu terbuat dari anyaman bambu dengan celah-celah berukuran kecil berbentuk hexagonal. Konstruksi ukuran mata bubu masih belum efektif untuk meloloskan ikan-ikan yang belum layak tangkap sehingga sangat mempengaruhi kelangsungan sumberdaya ikan. Tujuan dari penelitian ini adalah menganalisis tingkat selektivitas alat tangkap bubu dengan melihat komposisi hasil tangkapan. Pengumpulan data dilakukan dengan uji coba penangkapan menggunakan 4 unit bubu buton yang dipasangcover net sebanyak 20 kali ulangan. Penelitian dilakukan pada bulan September-Desember 2016 di Desa Wakal, Kabupaten Maluku Tengah. Jumlah total hasil tangkapan bubu sebanyak 353 ekor yang terdiri dari 63 spesies dan 22 famili. Komposisi ikan dominan adalah pada famili Achanthuridae, Scaridae, Holocentridae, Serranidae dan Lethrinidae. Presentasi ikan yang layak tangkap sebesar $76.34 \%$ dan tidak layak tangkap sebesar $23.66 \%$. Kurva selektivitasberdasarkan fungsi logistik menunjukkan bahwa peluang tertangkap ikan pada ukuran tinggi tubuh 9.5-19.5 cm, sedangkan ukuran ikan yang mampu meloloskan diri mempunyai tinggi tubuh sebesar 3.5-7.5 cm. Bubu yang digunakan nelayan tidak selektif terhadap jenis dan ukuran.
\end{abstract}

Kata kunci: bubu, desa wakal, ikan karang, selektivitas.

\begin{abstract}
Fishermen in Wakal Village still water use pot to catch coral fish species. The pot is made from woven bamboo with small hexagonal-shaped cracks. The mesh size construction of the pot are still ineffective to release undersized fish, this condition are greatly affect the sustainability of fish resources. The purpose of this research is to analyze the selectivity level of the potbased on catch composition. The data were collected by experimental fishingusing four units of pots were cover net in 20 repetitions. The research was conducted during September to December 2016 in Wakal Village, and Central Maluku Regency. Total number of fish caught by the pot was 353 individuals consist of 63 species and 22 families. The dominant of were fimily caught were Achanthuridae family, Scaridae, Holocentridae, Serranidae, and Lethrinidae. Percentage of fish caught and passed the equipment was $76.15 \%$ and $23.85 \%$ respectively. The selectivity curves based on the logistic function indicate the probability of fish caughtat body depth of 9.5-19.5 cm, while the body depth of fish that can escape from the pot was $3.5-7.5 \mathrm{~cm}$. The pots that used by fishermen are not selective in the fish species and size.
\end{abstract}

Keywords: coral fish, pot, selectivity, Wakal Village 


\section{PENDAHULUAN}

Nelayan di Perairan Desa Wakal, Kabupaten Maluku Tengah pada umumnya menggunakan bubu sebagai alat untuk menangkap ikan karang, dengan alasan biaya yang dikeluarkan untuk membuat dan mengoperasikan alat tangkap relatif murah. Bubu adalah suatu alat tangkap dengan bentuk dan ukuran yang bervariasi yang dipasang secara pasif dan dibuat sedemikian rupa sehingga memungkinkan ikan masuk ke dalamnya dan sulit untuk keluar (Subani \& Barus 1988). Menurut Sudirman dan Mallawa (2004) bubu merupakan alat penangkap ikan yang dipasang secara tetap dalam air untuk jangka waktu tertentu yang memudahkan ikan masuk dan sulit keluar. Secara umum bentuk bubu sangat beragam seperti: segi empat, trapesium, silinder, lonjong, bulat setengah lingkaran, persegi panjang, atau bentuk lainnya (Martasuganda 2008). Bentuk bubu biasanya disesuaikan dengan ikan yang menjadi target tangkapan. Namun, target ikan yang sama sering kali mengubah bentuk bubu tergantung pada kebiasaan atau pengetahuan nelayan yang mengoperasikannya. Bubu yang digunakan nelayan Desa Wakal berbentuk persegi dengan bahan utama terbuat dari anyaman bambu maupun rotan. Jenis-jenis ikan target penangkapan yang terdapat di terumbu karang ialah jenis ikan yang tergolong dalam famili Serranidae, Lutjanidae, Lethrinidae, Acanthuridae, Mullidae, Siganidae, Haemullidae, Labridae, Nemipteridae, Carangidae, dan Sphraenidae (Iskandar 2009; Riyanto 2011).

Konstruksi bubu yang digunakan oleh nelayan saat ini sangat mempengaruhi sumberdaya yang ada. Hal ini disebabkan karena ikan yang tertangkap dengan menggunakan alat tangkap bubu masih berukuran kecil atau belum layak tangkap. Kondisi ini sangat bertentangan dengan amanat Code of Conduct for Responssible Fisheries (CCRF) yang menitik beratkan pada selektivitas alat penangkapan ikan. Pada dasarnya bubu yang digunakan oleh nelayan di Desa Wakal belum memiliki tingkat selektivitas yang tinggi. Oleh karena itu, untuk menanggapi permasalahan di atas maka perlu dilakukan penelitian tentang tingkat selektivitas alat tangkap dengan menggunakan metode cover net (Sparre \& Venema 1999; Madsen et al. 2001; Frandsen et al. 2010; Yusrizal 2011; Sudirman et al. 2014; Tallo 2015). Menurut Matsushita et al. (1993) metode cover net adalah metode pemberian cover berupa jaring dengan mesh size yang kecil menutupi keseluruhan dari cod end, sehingga dengan mudah dapat membandingkan jumlah ikan di bubu dengan ikan yang terdapat dalam penutup bubu (cover net). Tujuan penelitian ini adalah untuk menganalisis komposisi hasil tangkapan bubu dan menganalisis tingkat selektivitas alat tangkap bubu di Perairan Desa Wakal.

\section{METODE PENELITIAN}

Penelitian dilakukan pada bulan September-Desember 2016 di perairan Desa Wakal, Kecamatan Leihitu, Kabupaten Maluku Tengah. Secara geografis Desa Wakal terletak pada $127^{\circ} 26^{\prime} 00^{\prime \prime}-130^{\circ} 10^{\prime}$ $00^{\prime \prime}$ BT dan $02^{\circ} 05^{\prime} 00^{\prime}-07^{\circ} 05^{\prime} 00$ LS (Gambar 1).

Kondisi oseanografi perairan selama penelitian adalah sebagai berikut: suhu permukaan air berkisar antara $25^{\circ} \mathrm{C}-27^{\circ} \mathrm{C}$, salinitas berkisar antara $25-28$ ppt. Bubu dipasang pada kedalaman $6-8 \mathrm{~m}$, dengan jarak dari pantai berkisar antara 100-200 m dengan subtrat dasar perairan karang-berpasir. Penelitian ini menggunakan eksperimental fishing dengan mengoperasikan empat unit bubu yang dilengkapi dengan cover net. Data yang dikumpulkan berupa jenis, jumlah (ekor), panjang total $(\mathrm{cm})$, dan lingkar tubuh ikan $(\mathrm{cm})$ dari hasil tangkapan pada setiap hauling. Alat yang digunakan dalam penelitian ini terdiri dari empat unit bubu buton dengan mesh size $6.28 \mathrm{~cm}$ dilengkapi dengan cover net, perahu motor tempel (armada penangkapan), papan ukurdengan ketelitian $0.1 \mathrm{~cm}$ (untuk mengukur panjang total ikan), meteran jahit dengan ketelitian $0.1 \mathrm{~cm}$ (mengukur keliling tubuh maksimum ikan), Global positioning System (GPS) (untuk menentukan lokasi penempatan alat tangkap bubu saat dioperasikan), Fish finder (untuk mengukur kedalaman serta suhu perairan), dan Refractometer (untuk mengukur salinitas perairan) sedangkan bahan yang digunakan ialah isi perut ikan sebagai umpan. 


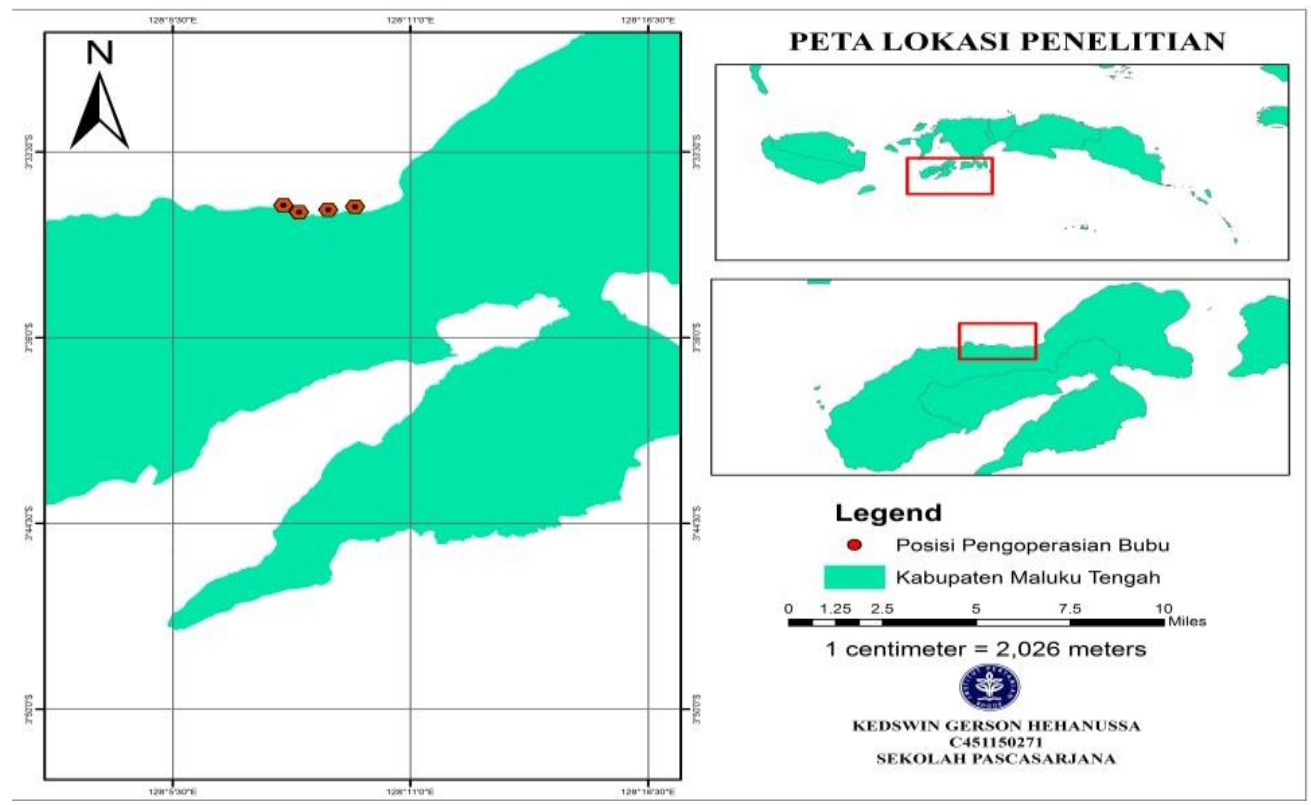

Gambar 1 Peta lokasi penelitian

\section{Konstruksi Bubu Buton}

Penelitian ini menggunakan bubu buton yang sering digunakan oleh nelayan untuk menangkap ikan karang. Bubu buton yang digunakan mempunyai dimensi p x 1 x t $(200 \mathrm{~cm}$ x $150 \mathrm{~cm}$ x $70 \mathrm{~cm})$. Mulut bubu tersebut berbentuk leher kuda dengan diameter mulut bubu bagian luar sebesar $40 \mathrm{~cm}$ dan bagian dalam $15 \mathrm{~cm}$. Jarak dari mulut bubu luar dengan mulut bubu bagian dalam sebesar $55 \mathrm{~cm}$. Ukuran dan konstruksi bubu yang digunakan disajikan pada Gambar 2.

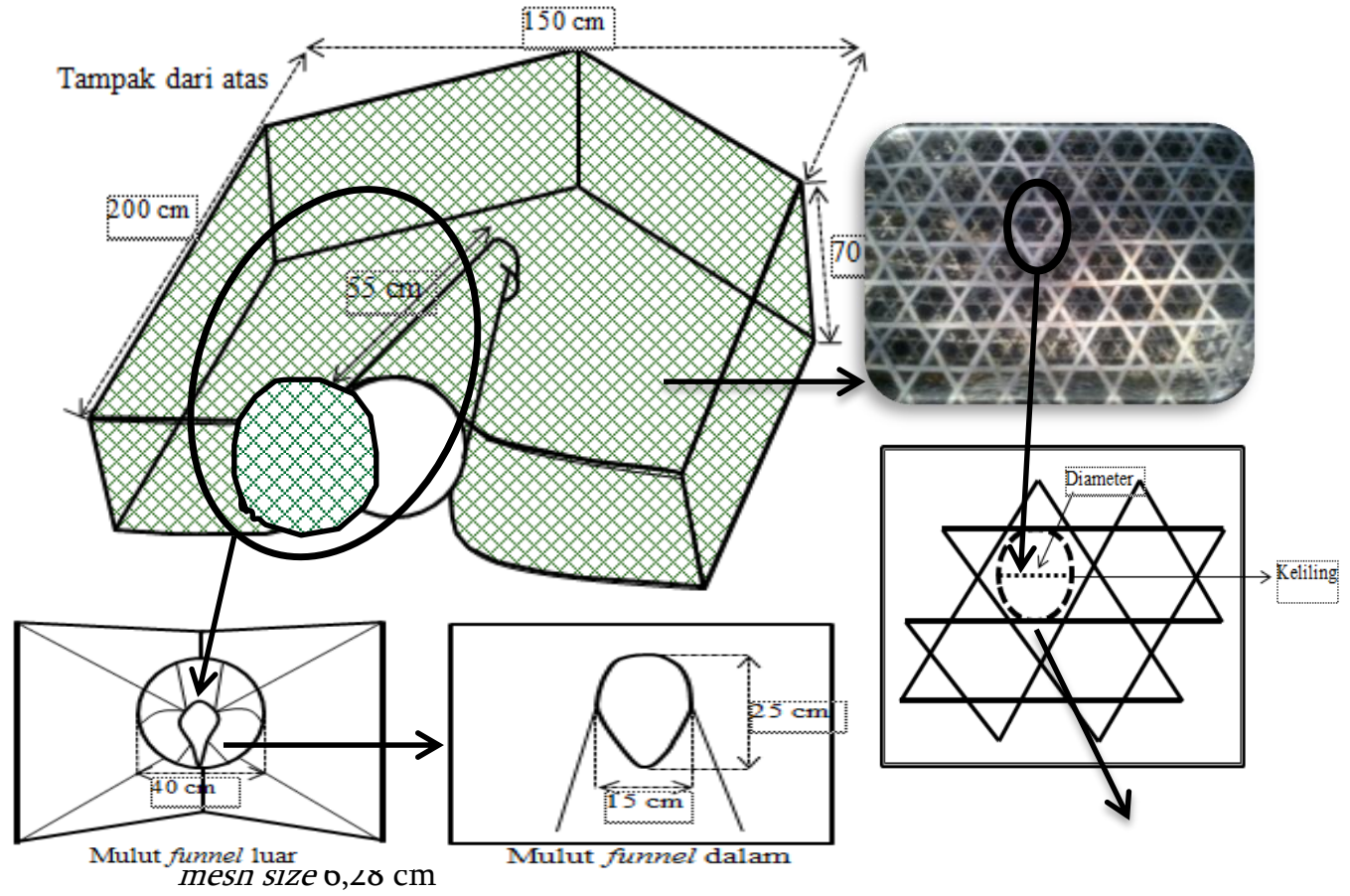

Gambar 2 Desain dan dimensi kerangka bubu

Bubu yang digunakan nelayan memiliki bentuk mata bubu yang berbeda dari alat tangkap lainnya, yaitu berbentuk seperti persegi enam atau berbentuk hexagonal dengan sisi-sisi ukuran yang sama. Ukuran mata bubu yang digunakan nelayan sebesar $6.28 \mathrm{~cm}$. Keempat bubu dioperasikan secara 
bersamaan. Lama waktu pengambilandata yaitu sebanyak 20 kali ulangan. Proses pemasangan bubu (setting) pada pagi hari sekitar (Pukul 08.00 WIT) dengan lama perendaman selama dua hari, kemudian di waktu yang sama kembali diangkat (hauling) pada pagi hari sekitar (Pukul 08.00 WIT). Jarak pemasangan antar bubu berkisar 300-400 m.

\section{Konstruksi Cover Net (Jaring Pembungkus)}

Pada bagian lubang pelolosan (mata bubu) dipasang kantong tambahan yang disebut cover net. Cover net terbuat dari bahan waring ukuran mata $3 \mathrm{~mm}$ dengan panjang keseluruhan $75 \mathrm{~cm}$ untuk empat bubu. Pemasangan cover net dibuat ke samping kiri, kanan dan atas sehingga ikan-ikan yang telah melewati mata bubu mudah masuk dan tertampung di cover net. Dengan cara ini dapat diketahui jumlah, jenis, dan ukuran ikan yang tertangkap dan yang lolos melalui mata bubu saat alat tangkap dioperasikan. Konstruksi cover net pada bubu yang digunakan disajikan Gambar 3.

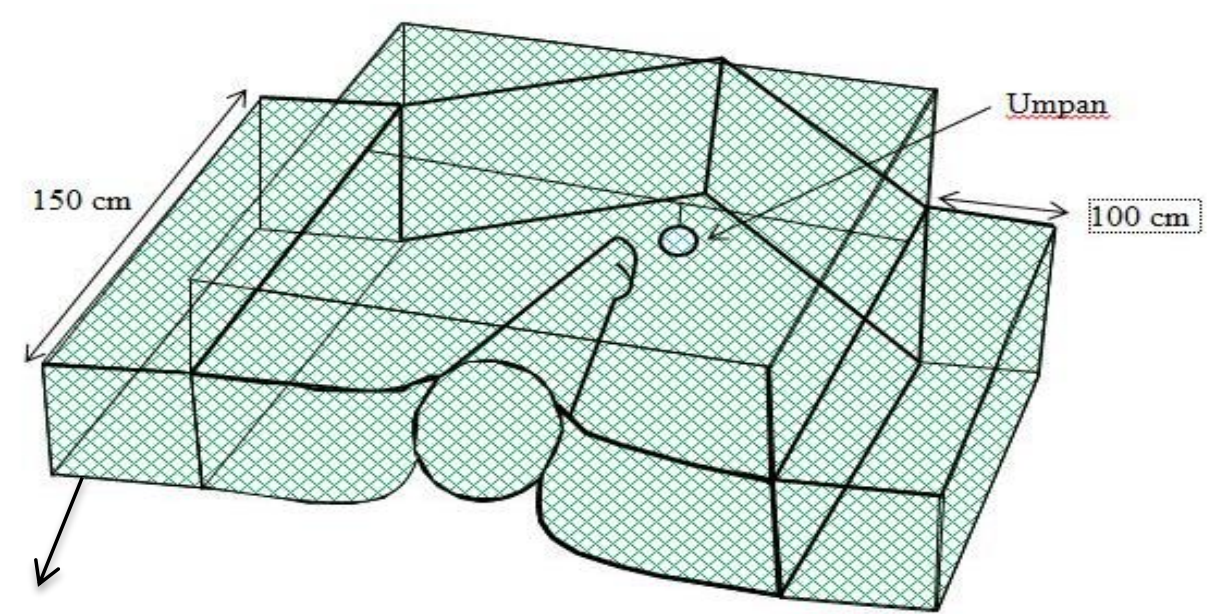

\section{Cover net}

\section{Gambar 3 Konstruksi cover net atau jaring pembungkus}

Konstruksi cover net pada bagian samping kiri, kanan dan atas badan bubu. Berdasarkan tingkah laku ikan saat berada dalam bubu ikan akan mencari jalan keluar dengan cara menyusuri dindingdinding bubu baik ke atas maupun ke samping sehingga peluang lolosnya ikan akan semakin besar.

\section{Analisis Data}

Analisis data yang digunakan yaitu analisis deskriptif tabulasidengan menjelaskan rangkaian kegiatan dari tahapan penelitian sampai pengoperasian alat tangkap di lapangan dan mendapatkan hasil tangkapan. Jumlah ikan yang tercatat disajikan dalam bentuk grafik komposisi hasil tangkapan. Hasil tangkapan dominan yang berada di dalam bubu diambil data panjang ikan (total length). Rumus untuk menentukan selang kelas dan interval kelas mengikuti petunjuk Walpole (1995) sebagai berikut.

$$
\begin{aligned}
K & =1+3.3 \log n \\
I & =R / K
\end{aligned}
$$

Dengan :

$$
\begin{array}{ll}
K & =\text { Jumlah kelas } \\
n & =\text { Banyaknya data } \\
I & =\text { Interval kelas } \\
R & =\text { Nilai terbesar-nilai terkecil }
\end{array}
$$


Selanjutnya untuk menghitung selektivitas alat tangkap dengan membandingkan hasil tangkapan yang ada di bubu dan penutup bubu menggunakan metode Sparre and Venema (1999) dengan rumus sebagai berikut.

Dengan:

$$
S(L)=1 /(1+\exp \alpha+\beta L)
$$

$S(L)=$ Peluang ikan tertangkap

$L=$ Maximum body depth

$\alpha, \beta=$ Variabel konstanta

Fungsi logistik dihitung dengan persamaan metode maximum likelihood dan didukung dengan program SOLVER pada Mikrosoft Excel. Persamaan metode maximum likelihood sebagai berikut:

$$
\begin{gathered}
L 50=-\alpha / \beta \\
S R=-2 \ln (3) / \alpha
\end{gathered}
$$

Sementara itu kurva proporsi kelolosan terbaik ditentukan dengan menggunakan nilai Akaike's Information Criterion (AIC) dengan rumus sebagai berikut:

$$
A I C=-2 M L L+2 M
$$

\section{Dengan:}

$M L L=$ Nilai-nilai dari Maximum log likelihood;

$M \quad=$ Jumlah variabel $\alpha \operatorname{dan} \beta$.

\section{HASIL}

\section{Komposisi dan Jumlah Total Hasil Tangkapan pada Bubu dan Cover Net}

Jumlah total hasil tangkapan bubu selama penelitian sebanyak 353 ekor dengan berat total 71,24 kg. jumlah spesies yang tertangkap sebanyak 63 spesies yang terbagi dalam 22 famili anatara lain jenis ikan kerapu (Serranidae), kakatua (Scaridae), Lalosi ekor kuning (Caesionidae), Kakap merah (Lutjanidae), Bubara (Carangidae) dan jenis ikan karang lainnya. Hasil tangkapan dominan dari segi jumlah adalah Achanthuridae 83 ekor (24.06\%), Scaridae 41 ekor (18.88\%), Holocentridae 31 ekor (8.99\%), Serranidae 25 ekor (7,25\%) dan Lethrinidae 23 ekor (6.67\%).

Dilihat dari jumlah spesies, maka hasil tangkapan yang dominan adalah Achanthurus nubilus 49 ekor (14.29\%), Scarus russelli 24 ekor (7\%), Plectrypops lima 24 ekor (7\%), Lethrinus laticaudis 17 ekor (4.95), dan Parupeneus rubescen 17 ekor (4.95\%). Komposisi jumlah hasil tangkapan bubu yang dominan tertangkap disajikan pada Gambar 4.

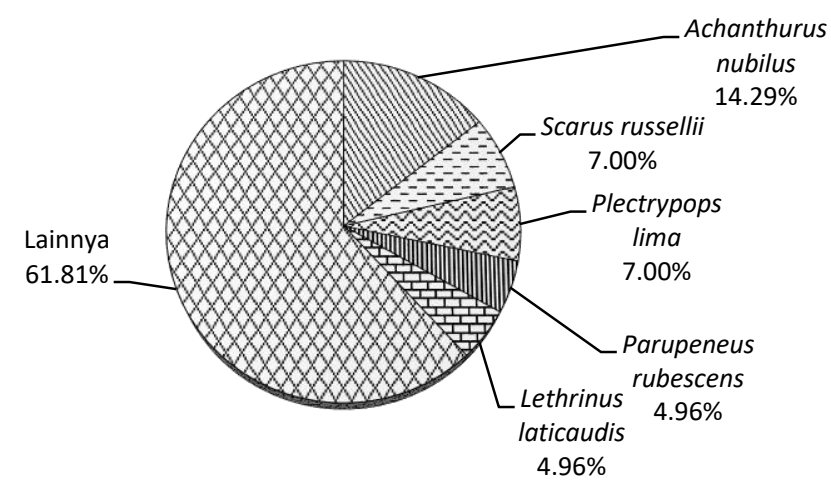

Gambar 4 Komposisi hasil tangkapan bubu yang dominan tertangkap berdasarkan jenis spesies. 
Jumlah total hasil tangkapan bubu terdiri dari hasil tangkapan utama dan hasil tangkapan sampingan dengan proporsi hasil tangkapan utama sebanyak 78\%, sedangkan proporsi hasil tangkapan sampingan sebanyak 22\%. Proporsi hasil tangkapan utama maupun sampingan disajikan pada Gambar 5.

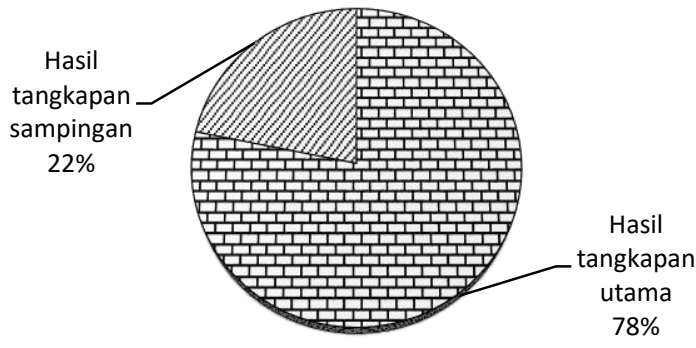

Gambar 5 Proporsi hasil tangkapan utama dan sampingan

Jumlah total hasil tangkapan yang ditangkap pada cover net sebanyak 10 spesies yang terbagi ke dalam 7 Famili. Dominan hasil tangkapanyang mampu meloloskan diri paling banyak pada famili Chaetodontidae dengan jenis spesies yaitu ikan kepe-kepe sebanyak 3 ekor. Komposisi hasil tangkapan pada cover net disajikan pada Gambar 6.

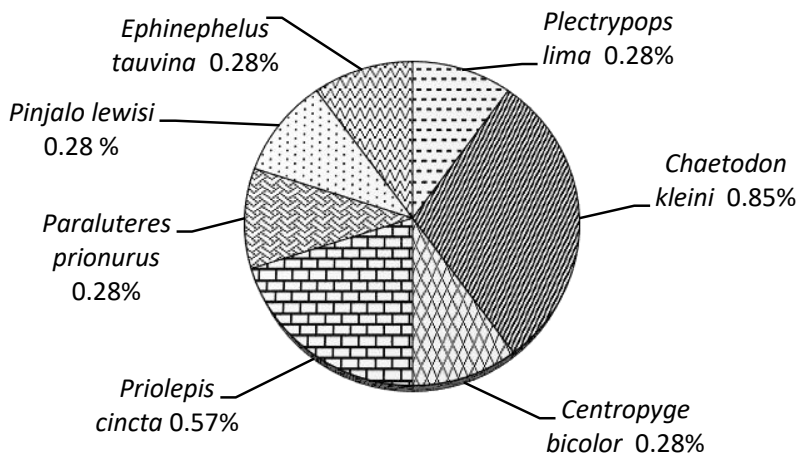

Gambar 6 Komposisi hasil tangkapan pada cover net

\section{Distribusi Ukuran Panjang Ikan yang Tertangkap}

Distribusi ukuran panjang ikan target tangkapan memiliki kisaran ukuran yang hampir seragam. Acanthurus nubilus tertangkap pada kisaran ukuran panjang total 22.65-38.25, Scarus russelli 12.85$31.85 \mathrm{~cm}$, Plectrypops lima 14.75-22.75 cm, Lethrinus laticaudis $19-40.5 \mathrm{~cm}$, dan Parupeneus rubescens 17.6-26.1 cm. Distribusi ukuran panjang ikan yang dominan tertangkap disajikan pada Gambar 7.

Pada Gambar 7 dapat dijelaskan bahwa jenis ikan target tangkapan yang layak tangkap terdiri dari ikan Acanthurus nubilus sebanyak 33 ekor sedangkan yang tidak layak tangkap sebanyak 16 ekor, Scarus ruselli yang layak tangkap sebanyak 11 ekor sedangkan tidak layak tangkap sebanyak 13 ekor, untuk Plectrypops lima yang layak tangkap sebanyak 22 ekor sedangkan yang tidak layak tangkap sebanyak 2 ekor dan untuk jenis ikan Lethrinus laticaudis dan Parupeneus rubescen dari gambar diatas pada umumnya merupakan target tangkapan yang sudah layak tangkap. 


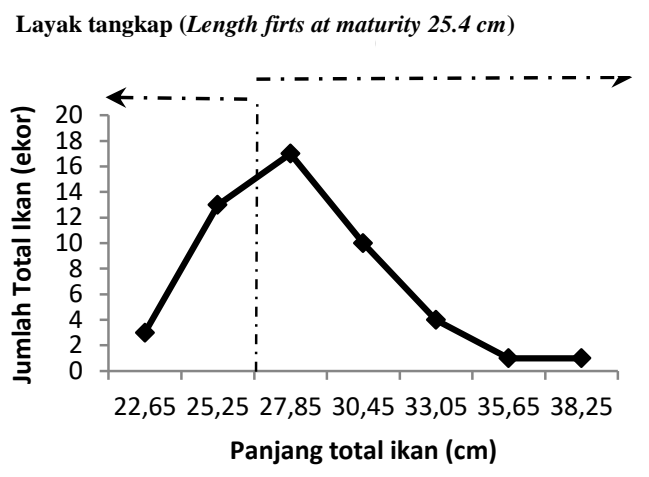

(a)

Layak Tangkap (Length firts at maturity $14.9 \mathrm{~cm}$ )

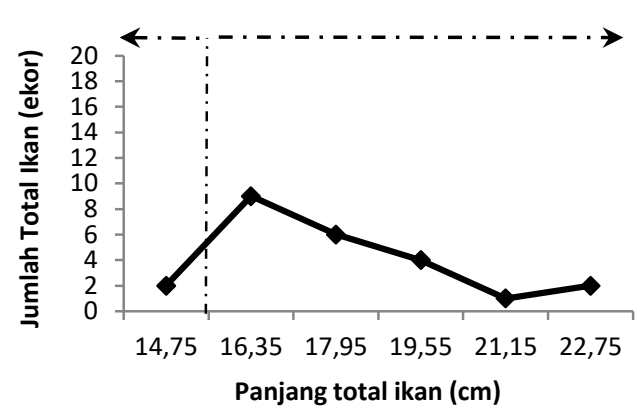

(c)
Layak Tangkap (Length firts at maturity $24 \mathrm{~cm}$ )

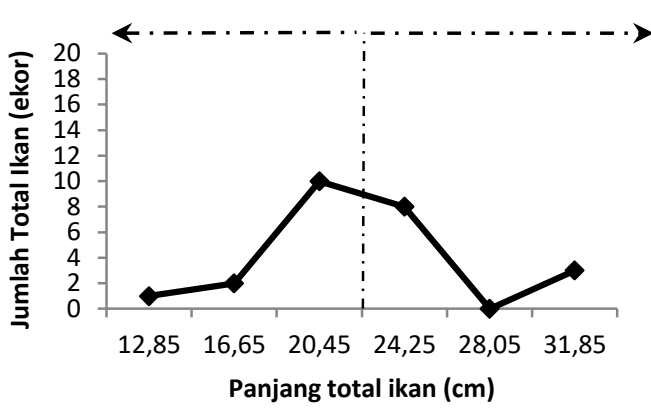

(b)

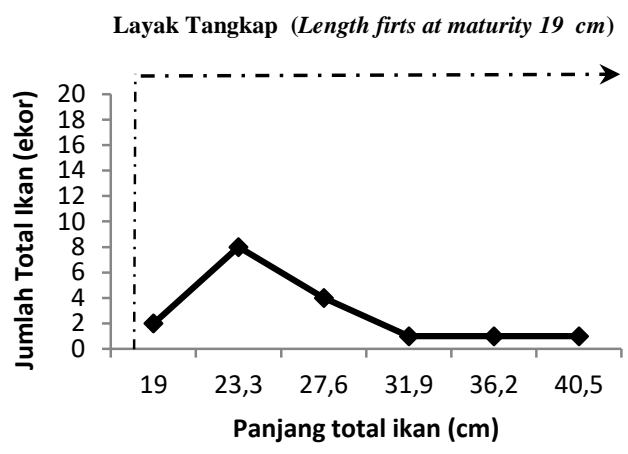

(d)

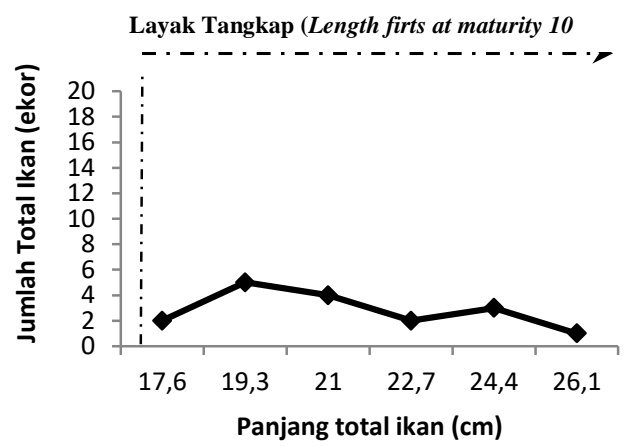

(e)

Gambar 7 Distribusi ukuran panjang ikan : (a) Achanthurus nubilus, (b) Scarus russelli, (c)

Plectrypops lima, (d) Lethrinus laticaudis, dan (e) Parupeneus rubescen

\section{Selektivitas Bubu}

Kurva selektivitas yang diperoleh menggunakan persamaan fungsi logistik, dapat dikemukakan bahwa hubungan antara peluang ikan yang tertangkap dengan ukuran tinggi tubuh maksimum (maximum body depth) sangat mempengaruhi selektivitas dari alat tangkap bubu. Hasil analisis selektivitas menunjukan sebanyak 50\% ikan yang tertangkap memiliki ukuran maksimum tinggi tubuh (maximum body depth) $6.8 \mathrm{~cm}$. Apabila variabelnya dimasukkan ke dalam model logistik, maka bentuk formulasinya adalah $S(L)=1 /\left(1+e x p^{-0,9787+6,6961^{*} \mathrm{~L}}\right)$. Kurva seletivitas bubu dapat disajikan pada Gambar 8 . 


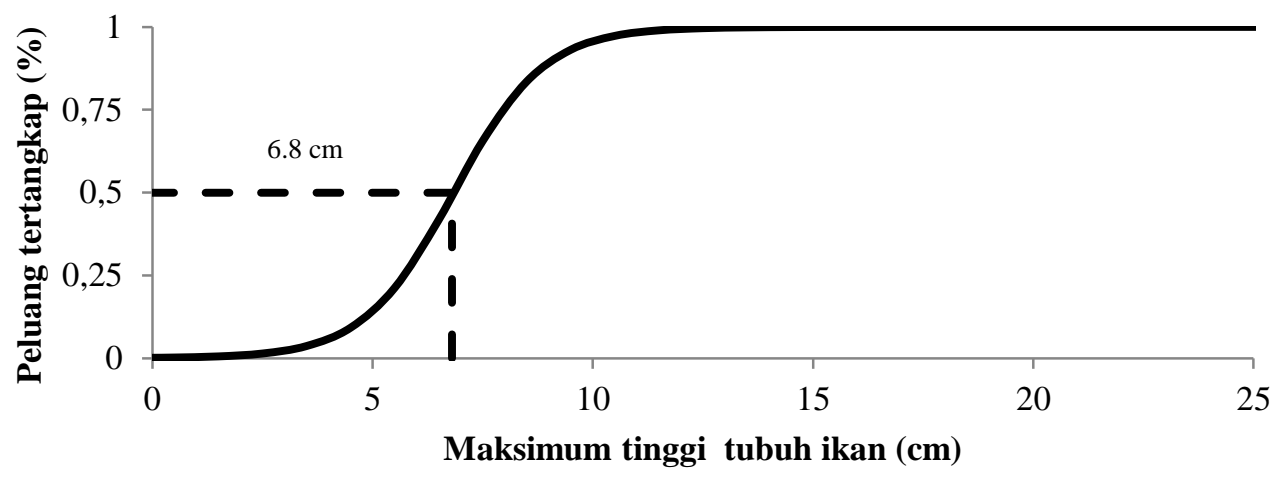

Gambar 8 Kurva selektivitas bubu

Hasil estimasi pada Gambar 8 terlihat bahwa hasil tangkapan bubu berada pada kisaran ukuran maksimum tinggi tubuh ikan 3.5-19.5 cm. Maksimum tinggi tubuh ikan yang tertangkap merupakan peluang terbesar untuk tidak dapat meloloskan diri kembali, artinya semakin besar ukuran maksimum tinggi tubuh ikan maka semakin besar pula peluang ikan untuk tertangkap. Peluang tertangkap ikan memiliki nilai maksimum sebesar $0.93-1.00 \%$ berada pada maksimum tinggi tubuh ikan (maximum body depth) $9.5-19.5 \mathrm{~cm}$. Ini berarti semua ikan dengan ukuran tinggi tubuh $9.5-19.5 \mathrm{~cm}$ tidak memiliki peluang untuk lolos namun hanya tertahan pada bubu, Sedangkan nilai peluang ikan untuk tertahan dan meloloskan diri maksimal sebesar L50 atau 50\% yaitu ikan yang memiliki maksimum tinggi tubuh $6.8 \mathrm{~cm}$.

\section{PEMBAHASAN}

Komposisi jumlah total hasil tangkapan didominasi oleh famili Acanthuridae, Scaridae, Holocentridae, Serranidae, dan Lethrinidae. Hal ini berhubungan erat dengan lokasi pemasangan bubu di perairan karang-berpasir dimana perairan tersebut merupakan tempat hidup bagi ikan-ikan karang, (Setiawan et al. 2013). Menurut Murdiyanto (2003) pada perairan karang terdapat famili ikan yang dominan antara lain Pomacentridae, Labridae, Serranidae, Apogonidae, Chaetodontidae, Scaridae, Acanthuridae, Blenniidae dan Gobiidae. Hasil tangkapan terbanyak adalah Acathuridae, ikan dari famili ini merupakan ikan diurnal yang aktif mencari makan pada siang hari (Setiapermana 1996). Hal itu terbukti dari hasil tangkapan pada siang hari dimana ikan ini lebih banyak tertangkap.

Jenis ikan yang berasal dari famili Acanthuridae merupakan target untuk penangkapan atau lebih dikenal juga dengan ikan ekonomis penting atau ikan konsumsi. Famili Acanthuridae memiliki keanekaragaman pola makan yang besar dengan memanfaatkan kelimpahan alga sebagai sumber makanan sehingga sebagian besar spesies Acanthurus adalah herbivora (Wibowo \& Adrim 2013). Pola makan herbivora dalam jumlah besar membuat Acanthuridae memberi pengaruh yang besar terhadap ekosistem terumbu karang. Hasil tangkapan lain yang dominan adalah Scaridae, Holocentridae, Serranidae, dan Lethrinidae. Ikan dari famili Scaridae, dan Lethrinidae merupakan Ikan diurnal yang aktif pada siang hari (Riyanto 2011). Ikan-ikan dari famili ini lebih banyak berasosiasi di terumbu karang pada waktu siang.Pada malam hari ikan-ikan diurnal akan masuk dan berlindung di dalam karang, keberadaan ikan tersebut akan digantikan oleh ikan-ikan nokturnal yaitu ikan yang aktif di malam hari. Mereka keluar pada malam hari untuk mencari makan, dan siang hari mereka masuk kembali ke celah- celah karang.Salah satu ikan nokturnal yaitu dari famili Holocentridae (Supriadi \& Nafie 2004).

Berdasarkan hasil tangkapan dominan yang diperoleh selama penelitian terdapat ukuran spesies yang termasuk ukuran layak tangkap dan tidak layak tangkap, Hal ini disesuaikan ukuran panjang saat pertama kali matang gonad (length first at maturity). Pada (Gambar 5) menunjukan bahwa sebanyak 76.34\% (100 ekor) ikan termasuk ukuran layak tangkap sedangkan yang tidak layak tangkap sebanyak 
23.66\% (31 ekor). Konstruksi ukuran bubu nelayan sangat mempengaruhi sumberdaya perairan karena ikan yang berukuran kecil maupun besar dapat masuk kedalam bubu. Hal tersebut disebabkan oleh ukuran Keliling bagian tengah dari pintu masuk bagian dalam sebesar $47.10 \mathrm{~cm}$ dengan tinggi pintu masuk $25.0 \mathrm{~cm}$, keliling ukuran mata bubu sebesar $12.56 \mathrm{~cm}$, dengan demikian ikan yang dapat masuk ke dalam Bubu adalah ikan yang mempunyai ukuran tinggi tubuh maksimum (maximum body depth) $\geq 6.28 \mathrm{~cm}$ dan atau ikan yang mempunyai keliling tubuh maksimum (Maximum body girth) $\geq 12.56 \mathrm{~cm}$ sampai dengan ukuran ikan yang mempunyai ukuran tinggi tubuh maksimum (maximum body depth) $\geq 25.0 \mathrm{~cm}$ dan atau ikan yang mempunyai keliling tubuh maksimum (Maximum body girth) $\geq 47.10 \mathrm{~cm}$. Jumlah ikan yang tidak layak tangkap memiliki ukuran keliling tubuh maksimum (Maximum body girth) adalah 14-20.6 cm, apabila disesuaikan dengan ukuran mata bubu maka rata-rata ukuran tinggi tubuh maksimum ikan (maximum body depth) adalah 7-10.3 cm. Hasil tangkapan dengan ukuran tidak layak tangkap seharusnya diloloskan agar sumberdaya perairan tetap terjaga dan tetap berkelanjutan. Oleh sebab itu, alat tangkap bubu masih belum selektif terhadap ukuran ikan yang tertangkap. Uraian diatas menjelaskan bahwa kesesuaian dari ukuran tinggi tubuh maksimum ikan (Maximum body girth) dari setiap jenis ikanterhadap ukuran mata bubu tidak mampu untuk meloloskan diri. Bila kondisi seperti ini terus terjadi maka akan mengganggu keseimbangan sumberdaya perairan. Oleh karena itu, salah satu strategi untuk melestarikan sumberdaya perikanan dapat dilakukan dengan memberi kesempatan terhadap ikan-ikan yang belum layak tangkap untuk melakukan pemijahan dan menjaga kelangsungan stok sebaiknya ikan diberikan kesempatan untuk memijah sekali (Effendi 1997).

Ukuran layak tangkap ikan diduga dipengaruhi oleh ukuran mata bubu dan konstruksi bubu (Riyanto 2008). Ukuran matabubu yang digunakan nelayan berukuran $6.28 \mathrm{~cm}$ sehingga lebih banyak ikan yang tertahan di dalam bubu bila dibandingkan dengan ukuran mata bubuyang lebih besar.Bubu yang dilengkapi celah pelolosan (escaping gap) memungkinkan ikan yang berukuran kecil (belum matang gonad) dapat lolos dengan mudah tanpa terluka (Purbayanto et al. 2006). Bentuk matabubu yang statis sangat mempengaruhi ikan saat meloloskan diri berbeda dengan mata jaring yang fleksibel dapat menyesuaikan bentuk tubuh ikan saat meloloskan diri. Menurut Stewart and Ferrell (2002); Tosunoglu et al. (2003) selektivitas ukuran mata jaringsangat dipengaruhi oleh bentuk dan tinggi tubuh ikan.Hal ini sejalan dengan pernyataan yang dikemukakan oleh Martasuganda et al. (2000) bahwa ukuran dan bentuk tubuh ikan sangat mempengaruhi selektivitas ukuran mata jaring. Bentuk tubuh ikan sangat mempengaruhi kemampuan ikan saat meloloskan diri, ikan yang mempunyai bentuk pipih dengan ukuran tinggi tubuh maksimum (maximum body depth) $\leq 6.28 \mathrm{~cm}$ atau ukuran keliling tubuh maksimum (maximum body girth) $\leq 12.56 \mathrm{~cm}$ memiliki kemampuan melewati mata bubu. Menurut Martasuganda (1999) pada bagian tubuh ikan terdapat titik taktil (teta point) sangat berpengaruh tehadap tingkat kelolosan ikan. Ikan akan meloloskan diri melalui mata bubu apabila bagian tubuh yang lolos sudah sampai melewati sirip punggung sedangkan ikan tidak dapat meloloskan diri apabila bagian tubuh ikan yang lolos hanya pada bagian operculum. Hal yang sama disampaikan oleh Herrmann et al. (2012) selektivitas ukuran mata dipengaruhi oleh morfologi ikan terutama pada bagian unjung opercular dan titik terdepan sirip punggung, artinya bahwa saat ikan meloloskan diri apabila menyentuh bagian opecular dan titik terdepan sirip punggung maka ikan tersebut tidak dapat meloloskan diri. Bubu buton yang digunakan nelayan memiliki ukuran mata bubu yang sama pada setiap badan bubu, seharusnya ikan yang bukan merupakan target tangkapan atau yang belum layak untuk ditangkap saat memasuki bubu lebih mudah menemukan celah untuk meloloskan diri. Kemampuan ikan saat menyeleksi ukuran mata bubu untuk meloloskan diri dipengaruhi oleh spesifikasi konstruksinya antara lain jenis material, bentuk dan ukurannya (Tallo 2015).

Hasil penenlitian menunjukkan bahwa jenis ikan dengan ukuran tinggi tubuh maksimum (maximum body depth)sebesar $7.5 \mathrm{~cm}$ mampu meloloskan diri ke dalam penutup kantong, Namun yang terjadi ditemukan adanya luka pada bagian kepala.Hal ini diduga karena bentuk dan ukuran mata bubu yang digunakan oleh nelayan mampu melukai tubuh ikan. Luka yang terdapat pada tubuh ikan dapat mengakibatkan kondisi yang buruk bagi kelangsungan hidupnya seperti berkurangnya kemampuan reproduksi (Lee \& Seed 1992; Abello et al. 1994; Raby et al. 2014), menurunnya laju pertumbuhan 
(Chitttieborough 1975; Davis 1981), berkurangnya kemampuan untuk mempertahankan diri (Simonson \& Hochberg 1986), dan berkurangnya kemampuan mencari makan bahkan kematian (Smith \& Hines (1991). Oleh sebab itu, diperlukan upaya pengembangan alat tangkap bubu melalui perbaikan teknologi atau modifikasi terhadap alat tangkap yang ada (Zulkarnain 2012). Celah pelolosan berbentuk lingkaran lebih efektif meloloskan ikan yang belum layak tangkap (Jeong et al. 2000). Estimasi ukuran mesh size bubu dapat mengacu kepada kurva selektivitas dalam penelitian ini digambarkan sebagai kurva probabilitas ikan yang tertangkap, sehingga ukuran mata bubu dapat dirubah atau disesuaikan dengan ukuran ikan yang menjadi target tangkapan. Desain dan konstruksi alat harus sesuai dengan ukuran spesies target sehingga dapat meminimalisir hasil tangkapan sampingan yang tidak diinginkan (Martasuganda 2008). Secara signifikan mengurangi spesies non target (Johnson 2010).

\section{KESIMPULAN DAN SARAN}

\section{Kesimpulan}

1. Total ikan di dalam bubu 353 ekor, terdiri dari 22 famili dengan 63 spesies, total ikan di dalam cover net 10 ekor. Jenis spesies target yang dominan tertangkap adalah Acanthurus nubilus 49 ekor (14.29\%), Scarus russelli 24 ekor (7\%), Plectrypops lima 24 ekor (7\%), Lethrinus laticaudis 17 ekor (4.95\%), dan Parupeneus rubescen 17 ekor (4.95\%).

2. Bubu buton dengan ukuran mata bubu (mesh size) $6.28 \mathrm{~cm}$ tidak dapat meloloskan spesies target yang belum layak tangkap dengan ukuran tinggi tubuh maksimum (maximum body depth) 7.0-10.3 $\mathrm{cm}$, dengan kata lain bubu yang digunakan masih belum selektif terhadap ukuran ikan yang tertangkap.

Saran

Untuk mengatasi permasalahan di atas, maka saran yang dapat diberikan kepada nelayan adalah konstruksi bubu buton perlu ditambah dengan celah pelolosan ikan yang memiliki diameter $10.3 \mathrm{~cm}$, dengan demikian diharapkan agar ikan target tangkapan untuk jenis Achanthurus nubilus, Scarus russelli, dan Plectrypops lima yang belum layak tangkap di bawah ukuran $\leq 10.3 \mathrm{~cm}$ dapat meloloskan diri.

\section{DAFTAR PUSTAKA}

Abello P, Warman CG, Reid DG, Neylor E. 1994. Chela loss in the shore crab (arcinus niaenas (Crustacea: Brachyura) and its effect on mating success. Mar. Bio.121: 247-252

Chittleborough RG. 1975. Environmental factors affecting growth and survival of juvenile western rock lobsters Panulirus longipes (Milne-Edwards). Marine and Freshwater Research. 26(2): 177196.

Davis GE. 1981. Effects of injuries on spiny lobster, Panulirus argusand implications for fisheries management. Fisheries Bulletin. NOAA.78:979-984.

Effendi MI. 1997. Biologi Perikanan. Yogyakarta (ID): Yayasan Pustaka Nusatama.

Frandsen RP, Madsen N, Krag LA. 2010. Selectivity and escapement behaviour of five commercial fishery species in standard square and diamond mesh codends. Journal of Marine Science. 67: $1721-1731$.

Herrmann B, Sistiaga MB, Nielsen KN, Larsen RB. 2012. Understanding the size selectivity of redfish (Sebastes spp.) in North Atlantic trawl codends. Journal of North Atlantic Fisheries Scinces. 44: $1-13$. 
Iskandar MD. 2009. Perbandingan komposisi dan variasi hasil tangkapan bubu tambun dengan celah pelolosan (Escape gap) dan tanpa celah pelolosan (Non Escape Gap). Jurnal Perikanan dan Kelautan Universitas Negeri Papua. 5(1): 9-20.

Jeong EC, Park CD, Park SW, Lee JH, Tokai T. 2000. Size selectivity of trap for male red queen crab Chionoecetes japonicus with the extended SELECT model. Fisheries Science. 66(3): 494-501.

Johnson EA. 2010. Reducing bycatch in coral reef trap fisheries: escape gaps as a step towards sustainability. Mar. eco.Prog. ser. 415: 201-209.

Lee SY, Seed R. 1992. Ecological implications of cheliped size in crabs: some data from Carcinus niaenas and Liocarcinus holsatus. Marine Ecology Progress Series. 84: 151-160.

Madsen N, Hansen KE, Poulsen T. 2001. The kite cover: a new concept for coverned codend selectivity studies. Fisheries Research. 49(3): 219-226.

Martasuganda S, Ogura Y, Matsuoka T, Kawamura G. 1999. Point against tactile stimulation and its effect to forward motion of fish upon contact with a mesh. Nihon Suisan Gakkaishi. 65(6): 991997.

Martasuganda S, Matsuoka T, Kawamura G. 2000. Effect of hang-in ratio on size-selectivity of gillnet. Nihon Suisan Gakkaishi. 66(3): 439-445.

Martasuganda S. 2008. Bubu (Traps). Departemen Pemanfaatan Sumberdaya Perikanan dan Pusat Kajian Sumberdaya Pesisir dan Lautan. Bogor (ID): Institut Pertanian Bogor.

Martasuganda S. 2008. Jaring Insang (Gillnet). Departemen Pemanfaatan Sumberdaya Perikanan dan Pusat Kajian Sumberdaya Pesisir dan Lautan. Bogor (ID): Institut Pertanian Bogor.

Matsushita Y, Inoue Y, Shevchenko AI, Norinov YG. 1993. Selectivity in the codend and in the main body of the trawl. Marine Science Symposia. 196: 170-177.

Murdiyanto B. 2003. Mengenal, Memelihara dan Melestarikan Ekosistem Terumbu Karang. Jakarta (ID): COFISH Project.

Purbayanto A, Husni E, Susanto A. 2006. Hasil tangkapan bubu laut dalam di teluk pelabuhanratu. Jurnal Ilmiah Pertanian Gakuryokushi. 12(2): 208-213.

Raby GD, Packer, JR, Danylchuk AJ, Cooke SJ. 2014. The understudied and underappreciated role of predation in the mortality of fish released from fishing gears. Fish and Fisheries. 15(3): 489-505.

Riyanto M. 2008. Respons Penciuman Ikan Kerapu Macan (Epinephelusfuscoguttatus) Terhadap Umpan Buatan [Tesis]. Bogor (ID): Institut Pertanian Bogor.

Riyanto M. 2011. Efektivitas penangkapan ikan kerapu macan (epinephelus fuscoguttatus) dengan bubu menggunakan umpan buatan. Jurnal Harpodon Borneo. 4(1): 21-32.

Setiapermana D. (1996). Potensi Wisata Bahari Pilau Mapor. Jakarta (ID): P30-LIPI.

Setiawan F, Razak TB, Idris, Estradivaria. 2013. Komposisi spesies dan perubahan komunitas ikan karang di wilayah rehabilitasi ecoreef PulauManado Tua.Taman nasional bunaken.Jurnal Ilmu dan Teknologi Kelautan Tropis. 5(2): 377-390.

Simonson JL, Hochberg RJ. 1986. Effects of air exposure and claw breaks on survival of stone crabs (Menippe mercenaria). Transactions of the American Fisheries Society. 115: 471-477.

Smith LD, Hines AH. 1991. The effect of cheliped loss on blue crab Callinectes sapidus rathbun foraging rate on softshell clams Mya arenaria L.Experimental Marine Biology and Ecology. 151(2):245256. 
Sparre P, Venema SC. 1999. Introduksi pengkajian stok ikan tropis. Jakarta (ID): Pusat Penelitian dan Pengembangan Perikanan Badan Penelitian dan Pengembangan Pertanian.

Subani W, Barus HR. 1989. Alat Penangkapan ikan dan udang laut di Indonesia. Edisi Khusus. Jurnal Penelitian Perikanan Laut. Jakarta (ID): Balai Penelitian Perikanan Laut. Badan Penelitian dan Pengembangan Pertanian. Departemen Pertanian.

Sudirman, Baskoro MS, Purbayanto A, Monintja DR, Arimoto T. 2014. Perfomans selektivitas alat tangkap bagan ambo di Perairan Barru Selat Makasar. Torani Unhas. 14(1): 1-14.

Sudirman, Mallawa A. 2004. Teknik penangkapan ikan. Jakarta (ID): Rineka cipta.

Supriadi BI, La Nafie YA. 2004. Inventarisasi jenis, kelimpahan dan biomassa ikan di padang lamun Pulau Barranglompo Makasar. Torani. 14(5): 288-295.

Stewart J, Ferrell JD. 2002. Mesh selectivity in the New South Wales demercal traps fishery. Fish. Res. 59: 379-392.

Tallo I. 2015. Rancang Bangun Bubu Lipat dalam Upaya Peningkatan Efektivitas dan Efisiensi Penangkapan Kepiting Bakau yang Ramah Lingkungan [disertasi]. Bogor (ID): Institut Pertanian Bogor.

Tosunoglu Z, Ozbilgin DY, Ozbilgin H. 2003. Body shape and trawl cod end selectivity for nine commercial fish species. Marine Biological Association of the United Kingdom.83: 1309-1313.

Walpole. 1995. Pengantar statistika. Diterjemahkan oleh Bambang Sumantri.Cetakan ke enam. Jakarta (ID): PT Gramedia.

Wibowo K, Adrim M. 2013.Komunitas ikan-ikan karang di Teluk Prigi Trenggalek, Jawa Timur.Zoological Indonesia. 22(2): 29-38.

Yusrizal. 2011. Perbandingan Penggunaan Ukuran Mata Jaring Bagian Kantong pada Trawl Dasar di Perairan Tanjung Kerawang [tesis]. Bogor (ID): Institut Pertanian Bogor.

Zulkarnain. 2012. Rancang Bangun Bubu Lipat Modifikasi dan Penggunaan Cacing Tanah (Lumbricus Rebellus) Sebagai Umpan Alternatif Untuk Penangkapan Spiny Lobster [disertasi]. Bogor (ID): Institut Pertanian Bogor. 